\title{
Late diagnosis of oral cancer: how to face it under the Family Health Strategy.
}

\section{Diagnóstico tardio do câncer oral: como enfrentá-lo na Estratégia Saúde da Família.}

\section{El diagnóstico tardío del cáncer oral : cómo enfrentarlo en la Estrategia Salud de la Familia.}

\author{
Nilce Santos MELO ${ }^{1}$ \\ Paulo Tadeu FIGUEIREDO ${ }^{2}$ \\ André Ferreira LEITE ${ }^{3}$ \\ Filipe Ramos BARRA ${ }^{4}$ \\ Gilberto Alfredo PUCCA JR 5
}

RESUMO: Este artigo apresenta ferramentas para lidar com o diagnóstico tardio do câncer bucal no Brasil, com base na Estratégia de Saúde da Família (ESF). A ESF é uma política pública de saúde. Ela representa uma ruptura com a organização disciplinar tradicional, muito fragmentada e dirigida ao aspecto biológico do processo saúde-doença, fornecendo um caminho para médicos, dentistas, enfermeiros e outros profissionais da saúde para estabelecer ligações entre o conhecimento específico em cada área. Nesse contexto, o presente artigo apresenta os seguintes instrumentos para lidar com o atraso no diagnóstico de câncer bucal: a educação continuada para a equipe de saúde bucal; a identificação de pacientes de risco, o acesso invertido e a garantia do exame obrigatório para pacientes com idade acima de 50 anos, fumantes e ou etilistas. Investir em educação continuada pode ser a chave para reduzir as barreiras associadas ao diagnóstico precoce do câncer bucal.

Palavras-chave: diagnóstico tardio, câncer oral, Estratégia Saúde Família

Conflito de interesse: não há

\begin{abstract}
This article presents tools for dealing with the late diagnosis of oral cancer in Brazil, based on the Family Health Strategy (FHS). The FHS is a public healthcare policy. It represents a rupture with the traditional, fragmented disciplinary organization much directed to the biological aspect of the health-disease process, what gives a way for physicians, dentists, nurses and other healthcare professionals to establish links between the specific knowledge in each area. In this context, this article presents the following instruments for dealing with the delay in diagnosing 1 Professor Adjunto do Departamento de Odontologia, Faculdade de Ciências da Saúde. Universidade de Brasília. nilcesantosmelo@gmail.com

2 Professor Adjunto do Departamento de Odontologia, Faculdade de Ciências da Saúde. Universidade de Brasília. paulofigueiredo@unb.br

3 Professor Adjunto do Departamento de Odontologia, Faculdade de Ciências da Saúde. Universidade de Brasília. andreleite@unb.br

4 Médico, aluno do Programa de Pós-graduação em Ciências da Saúde, Faculdade de Ciências da Saúde.

Universidade de Brasília. filipebarra@gmail.com

5 Professor Adjunto do Departamento de Odontologia, Faculdade de Ciências da Saúde. Universidade de Brasília. gilberto.pucca@ig.com.br
\end{abstract}


oral cancer: continuing education for the oral health team; the identification of patients at risk, the access inversion, and the guarantee of the mandatory exam for patients aged over 50 years old, smokers and or alcohol addicts. Investing in continuing education may be key to reduce the barriers associated to oral cancer early diagnosis.

Keywords: late diagnosis, oral cancer, Family Health Strategy

RESUMEN: El artículo presenta las herramientas para tratar con la demora en el diagnóstico de cáncer oral en Brasil, sobre la base de la Estrategia Salud de la Familia (ESF). El ESF es una política de salud pública. Representa una ruptura con la organización disciplinaria tradicional, muy fragmentada y dirigida al aspecto biológico del proceso salud-enfermedad, proporcionando uma manera para que los médicos, dentistas, enfermeras y otros profesionales de la salud establezcan vínculos entre los conocimientos específicos en cada área. En este contexto, en el presente trabajo, se presentan los siguientes instrumentos para hacer frente a la demora en el diagnóstico de cáncer oral: la educación continua para el equipo de salud oral; la identificación de los pacientes en situación de riesgo, acceso inversión y la garantía del examen obligatorio para los pacientes de edad más de 50 años de edad, fumadores y bebedores. Invertir en la educación continua puede ser clave para reducir las barreras asociadas al diagnóstico precoz del cáncer oral.

Palavras-clave: demora en el diagnóstico, cáncer oral, Estrategia Salud de la Familia

\section{INTRODUCTION}

Oral cancer causes cosmetic deformity, physical destruction and loss of function of the affected organs, what leads to a serious public health issue in Brazil. The world's estimated yearly incidence rate is 275 thousand cases for oral cancer and 130 thousand for pharyngeal cancer, with higher prevalence in Pakistan, India, Thailand, Slovakia and Brazil. ${ }^{1-4}$

In Brazil there have been 15,290 oral cancer cases estimated for $2014 .{ }^{5}$ In line with the reality in the world, about two thirds of all oral cancer cases are diagnosed late, what increases their socialeconomic impact. The delay may take up to five months [6]. Figures 1, 2 and 3 are based on several studies and show factors that may aid in understanding the late diagnosis for oral cancer in Brazil and in other countries. ${ }^{6-10}$ The need for continuing education for healthcare professionals is one of these determining factors. Therefore, there is a need to improve public health education programs in order to promote new competences and knowledge that will reduce the impacts and the time spent between self-perception of signs and symptoms all the way until therapy. 
Figure 1. Major factors of delayed diagnosis related to professionals (based on previous studies) ${ }^{6-10}$

\begin{tabular}{|l|}
\hline Cognitive interpretation of symptoms (ignorance / knowledge) \\
\hline Conflicts of responsibility (co-morbidity) \\
\hline Distance to specialist services \\
\hline Lack of complete clinical examination \\
\hline Low level of suspicion \\
\hline Ignorance of potentially malignant lesions \\
\hline Ignorance of early signs of disease \\
\hline Lack of involvement of healthcare professionals in the diagnosis of oral cancer \\
\hline
\end{tabular}

Figure 2. Major factors of delayed diagnosis related to access (based on previous studies). ${ }^{6-10}$

\begin{tabular}{|l|}
\hline Lack of provision of diagnostic services \\
\hline Lack of staff \\
\hline Inadequate time \\
\hline Health system based on hospital-centered model \\
\hline Access not based on the Family Health Program \\
\hline Distance of oral healthcare services \\
\hline Need for referral for care in specialized centers \\
\hline
\end{tabular}

Figure 3. Major factors of delayed diagnosis related to patients (based on previous studies). ${ }^{6-10}$

\begin{tabular}{|l|}
\hline Misperception of symptoms and use of alternative therapies \\
\hline Misperception of presenting a "simple injury" \\
\hline Unknowing that oral cancer is increased in smokers \\
\hline Related to age, where young patients do not suspect they may be susceptible \\
\hline Psychological factors such as the fear of having cancer and the family tensions that would generate \\
Care with wrong professionals \\
\hline
\end{tabular}

Thus, the Ministry of Health in Brazil has elaborated a program called Family Health Strategy (FHS) intended at changing the traditional way of delivering care. The FHS aims at providing full care to the user as a subject integrated to the family, his/her home and the community.

Since 2004, the Oral Health National Policy has proposed a reorientation of the healthcare model, supported by an adaptation of the working system of Oral Health teams so that they include actions of health promotion, protection and recovery. Human resources should be prepared to act in this system. The qualifying process must take in consideration knowledge evolution, changes in the work process and changes in demographical and epidemiological aspects, according to a perspective of maintaining a balance between technique and social relevance. ${ }^{11}$

The Family Health Strategy proposes, therefore, to halt the traditional, fragmented disciplinary organization much directed to the biological aspect of the health-disease process, what gives a way for physicians, surgeon dentists, nurses and other healthcare professionals to establish links between the specific knowledge in each area in order to propose new practices. Among these professionals, one can mention the community health agent (CHA) that carries out home visits. ${ }^{11-14}$ 
The inclusion of Oral Health in the Family Health Strategy, launched in 2001, represented the possibility of creating a space for practices and relationships to be built for the reorientation of the work process itself and the role of oral healthcare within overall healthcare services. Thus, oral healthcare has demanded the establishment of a working group that relates to users and that participates in the management of services in order to meet the demands of the population and expand access to programs and services for the promotion, prevention and recovery of oral health by means of collective action measures and territorial bonds. ${ }^{11,12}$

From December 2002 to September 2010, 15,842 new Oral Healthcare Teams (OHT) within the Family Health Strategy were established, thus reaching a total of 20,103 OHTs, acting in 4,811 municipalities, representing $86.5 \%$ of all Brazilian municipalities. Currently, about 70 million Brazilians have been covered by the actions of oral healthcare teams. It is within this new context of healthcare coverage that the population may be granted with instruments that determine early detection of oral cancer, including investment in training. ${ }^{13,15}$

\section{Training model for healthcare professionals as a tool for early diagnosis}

Training professionals, whether face-to-face or at a distance, must be thought over as to the form and goals set forth in order to have an impact on oral cancer morbidity and mortality indicators. Training should not be restricted to the detection of mouth lesions, but must also be directed towards smoking cessation. In an era of evidence-based healthcare, one might question the effectiveness of current teaching methods and their influence on health inequalities in oral health. ${ }^{16}$

Capacity-building should not be done in isolation, leading to duplication and conflicting messages delivered to the public. Also, training in oral health should not focus on changing individual behavior and nor ignore the influence of social and political factors as major determinants of health. ${ }^{16}$ Training courses created with a collective and collaborative approach could have a positive influence on the attitude and behavior of participants, of the knowledge on oral cancer and potentially would make a difference in the prevention, early detection and also work for tracking patients in initial stages or under risk factors. The modules for continuing education must address tobacco use, how to encourage the abandonment and the early detection of oral cancer. The specific module for the early detection of oral cancer should cover the epidemiology, differential diagnosis, early signs and symptoms, potentially malignant oral lesions, clinical presentation of oral cancer, diagnostics such as cytology and biopsy for diagnosis. ${ }^{16,17}$

The required new look at continuing education through the integration of new learning technologies should be directed not only to surgeon-dentists. The entire healthcare team should be involved, including community health workers, who are part of the healthcare team that conducts home visits. During these visits, community workers identify smokers and alcoholics in the families and have them registered at a specific file card. The identification of patients at high risk of oral cancer is the second instrument to cope with delayed diagnosis under the context of the Family 
Health Strategy.

\section{CHA: identification of risk patients and access inversion}

The fact to the matter is to be able to identify patients at risk. All members of health teams must identify patients at high risk for oral cancer. In order to do so, we need to expand the powers of the CHA in promoting oral health, to build knowledge contributions consistent with the interdisciplinary approach of the Family Health Strategy. The community health agent may receive continuing education and skills to detect the loss of normal oral tissues. As the mouth is easy to access, this screening activity would be essential to ensure patients at risk have access to a dental appointment.

With the integration of community health workers we could eliminate another barrier that is the demand of the patient for health services. The reversal of the path between the patient and the health service should be a commitment of the team. During visits, community health agents can identify smokers aged over 50 years, drinkers and grant them access to dental services in primary care. This is the third instrument to cope with delayed diagnosis of oral cancer and involves accessibility and opportunity.

\section{Guarantee of mandatory testing for patients 50 years or older, that are smokers or drinkers}

Patients over 50 years should have easier access to healthcare and guaranteed an appointment with a dentist, with a view to the diagnosis of premalignant lesions or early diagnosis of oral cancer. The appointment should not be limited to clinical examination, but it must also include the minimum approach for smoking cessation.

This approach also means to invert the Brazilian healthcare system in oral health once traditionally focused on children and adolescents. Surgeon-dentists and physicians must consider high-risk patients very carefully (above 50 years old, fair-skinned people exposed to the sun, smokers and alcoholics) and high-risk places. ${ }^{18-20}$

\section{CONCLUSIONS}

Given the indicators, which have been stable for over forty years, we clearly see the need to establish new ways of coping with delayed diagnosis of oral cancer. More than ever we must remove the blame of healthcare professionals who actually see one or two cases of cancer during their career. We must encourage these professionals towards the elimination of risk factors and ensure consideration for smokers or alcoholics. ${ }^{18}$

Primary care is featured as a privileged space for the control of risk factors, early diagnosis and healthcare of cancer patients. However, patients with oral cancer are generally accepted as spontaneous demand, and, in many cases start at a primary phenomenon of repeated delays, the 
reference diagnosis, ultimately delaying the potential for earlier treatment and therefore limit the chances of survival. ${ }^{10}$ The joint work of the healthcare team provides the alignment of the performance of community health workers, public dentists, private dentists, specialists and all other health professionals, for the elimination of risk factors.

While aware of the scope of these actions and their domestic political framework it becomes clear that aspects of the tumor cannot be disregarded. The tumor aggressiveness may be the determining factor in the evolution and prognosis. ${ }^{21}$

Hence, in the context of the Brazilian Family Health Strategy, this article presents tools for coping with the delay in the diagnosis of oral cancer. To address these activities it is necessary to consolidate the network of reference and counter-reference between the departments of primary and secondary care. Public actions on oral health must involve both preventive and curative procedures aiming to minimize the oral health distortions still prevailing in developing countries, such as in Brazil. ${ }^{22}$ These actions, aside from being exclusive of the Brazilian program Family Health Strategy, are in line with the guidelines of the World Health Organization ${ }^{23}$ and can be replicated in other contexts. The suggested instruments in this article may improve oral cancer management, reducing the diagnostic delay of the disease. Considering that the delay may be related to patient, professional and/or the healthcare system, a multidisciplinary approach should be mandatory. All educational methods to improve the knowledge of the clinicians and to raise public awareness with respect to oral cancer should be employed. ${ }^{10}$

\section{REFERENCES}

1. International Agency for Research on Cancer/World Health Organization. Available from: http://globocan.iarc.fr/Pages/fact_sheets_cancer.aspx (accessed 21.05.2015)

2. Warnakulasuriya S. Global epidemiology of oral and oropharyngeal cancer. Oral Oncol. 2009;45:309-16.

3. de Camargo Cancela M, Voti L, Guerra-Yi M, Chapuis F, Mazuir M, Curado MP. Oral cavity cancer in developed and in developing countries: population-based incidence. Head Neck. 2010;32:357-67.

4. Curado MP, Hashibe M. Recent changes in the epidemiology of head and neck cancer. Curr Opin Oncol. 2009;21:194-200.

5. Brasil. Ministério da Saúde. Instituto Nacional do Câncer. INCA. Estimativa 2014: Incidência de Câncer no Brasil. Rio de Janeiro: INCA; 2014.

6. Abdo EN, Garrocho Ade A, Barbosa AA, Oliveira EL, Franca-Filho L, Negri SL, Pordeus IA. Time elapsed between the first symptoms, diagnosis and treatment of oral cancer patients in Belo Horizonte, Brazil. Med Oral Patol Oral Cir Bucal. 2007;12:E469-73. 
7. Yu T, Wood RE, Tenenbaum HC. Delays in diagnosis of head and neck cancers. J Can Dent Assoc. 2008;74:61.

8. Gómez I, Warnakulasuriya S, Varela-Centelles PI, López-Jornet P, Suárez-Cunqueiro M, Diz-Dios P, Seoane J. Is early diagnosis of oral cancer a feasible objective? Who is to blame for diagnostic delay? Oral Dis. 2010;16:333-42.

9. Wade J, Smith H, Hankins M, Llewellyn C. Conducting oral examinations for cancer in general practice: what are the barriers? Fam Pract. 2010;27:77-84.

10. Güneri P, Epstein JB. Late stage diagnosis of oral cancer: components and possible solutions. Oral Oncol. 2014;50:1131-6.

11. Junqueira SR, Pannuti CM, Rode Sde M. Oral health in Brazil--part I: public oral health policies. Braz Oral Res. 2008;22 Suppl 1:8-17.

12. Brasil. Ministério da Saúde. Diretrizes da Política Nacional de Saúde Bucal, 2004. Ministério da Saúde archive Available from: http://www.saude.gov.br/bucal. (Acessed 20 mar 2015).

13. Pucca Junior GA, Lucena EH, Cawahisa PT. Financing national policy on oral health in Brazil in the context of the Unified Health System. Braz Oral Res. 2010;24 Suppl 1:26-32.

14. Levy FM, Matos PE, Tomita NE. [Community health agent program: perception by patients and health service workers]. Cad Saude Publica. 2004;20:197-203.

15. Pucca GA Jr, Costa JF, Chagas Lde D, Sivestre RM. Oral health policies in Brazil. Braz Oral Res. 2009;23 Suppl 1:9-16.

16. Silverman S Jr, Rankin KV. Oral and pharyngeal cancer control through continuing education. J Cancer Educ. $2010 ; 25: 277-8$.

17. Silverman S Jr, Kerr AR, Epstein JB. Oral and pharyngeal cancer control and early detection. J Cancer Educ. 2010;25:279-81.

18. Sheiham A, Watt RG. The common risk factor approach: a rational basis for promoting oral health. Community Dent Oral Epidemiol. 2000;28:399-406.

19. Epstein JB, Gorsky M, Cabay RJ, Day T, Gonsalves W. Screening for and diagnosis of oral premalignant lesions and oropharyngeal squamous cell carcinoma: role of primary care physicians. Can Fam Physician. 2008;54:870-5.

20. Williams PM, Poh CF, Hovan AJ, Ng S, Rosin MP. Evaluation of a suspicious oral mucosal lesion. J Can Dent Assoc. 2008;74:275-80.

21. Seoane J, Pita-Fernández S, Gómez I, Vazquez I, López-Cedrún JL, De Agustin D, VarelaCentelles P. Proliferative activity and diagnostic delay in oral cancer. Head Neck. 2010;32:137784. 
22. Pedrazzi V, Dias KR, Rode Sde M. Oral health in Brazil--part II: dental specialty centers (CEOs). Braz Oral Res. 2008;22 Suppl 1:18-23.

23. Petersen PE. Oral cancer prevention and control--the approach of the World Health Organization. Oral Oncol. 2009;45:454-60.

Artigo apresentado em 22-05-15 Artigo aprovado em 02-08-15 Artigo publicado no sistema em 26-09-15 